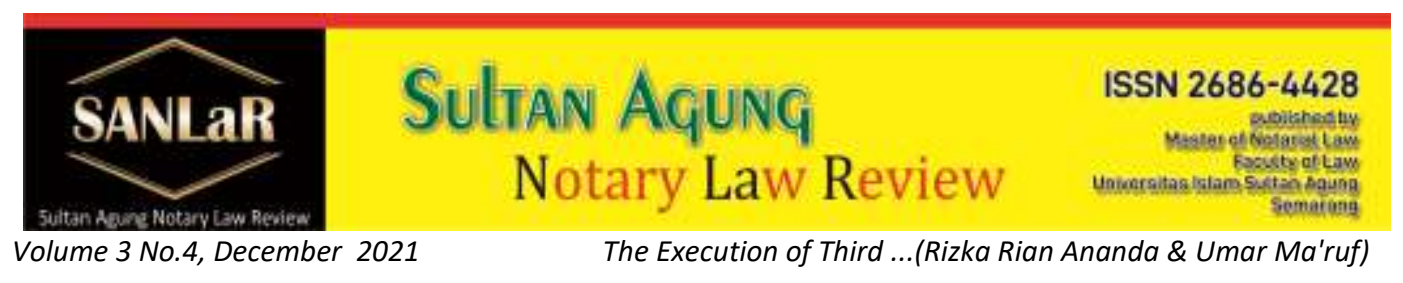

\title{
The Execution of Third Party Mortgage Guarantees in Rural Bank Credit Agreements
}

\author{
Rizka Rian Ananda*) and Umar Ma'ruf ${ }^{* *}$ \\ *) Faculty of Law, Universitas Islam Sultan Agung (UNISSULA) Semarang, E-mail: \\ kahamisena@gmail.com \\ ${ }^{* *}$ Faculty of Law, Universitas Islam Sultan Agung (UNISSULA) Semarang, E-mail: \\ umar@unissula.ac.id
}

\begin{abstract}
This study aims to determine the execution of mortgage guarantees on bank credit agreements belonging to third parties at Rural Banks. The Method approach in this research is empirical juridical with primary and secondary research data taken by interview and literature review. Data analysis method using qualitative analysis. The results of the study indicate that the execution of mortgage rights belonging to third parties in BPR $X$ is in accordance with the rules in Article 1 and Article 6 of Act No. 4 of 1996 concerning Mortgage Rights and carried out by the KPKNL. The execution of mortgage rights belonging to third parties in the BPR credit agreement in the event of a fight must be able to show proof of ownership but the execution process must still be carried out. Legal remedies for third parties as owners of land rights that are used as objects of mortgage rights are that they can file a lawsuit or derden verzet to the District Court, although this method cannot in principle suspend execution (Article 207 paragraph (3) HIR and $227 \mathrm{RBg}$ ) especially if from the start the third party agrees that the land is used as collateral for mortgage rights.
\end{abstract}

Keywords: Execution; Guarantee; Mortgage; Party; Third.

\section{Introduction}

One sector that is very influential on the development of the national economy is banking. The influence of banking in the national economy is related to the function of equity, stability and economic growth to increase people's welfare. ${ }^{1}$ An important function of banking as written in the banking law is to collect deposits and then distribute them to the public in the form of credit. With this banking function, it is expected that banks can control the monetary stability

\footnotetext{
${ }^{1}$ Thomas Suyatno, (2001), Kelembagaan Perbankan, Jakarta: Gramedia Pustaka Utama, p.1
} 
system of a country because through banking there is a circulation of money in society. ${ }^{2}$

The role of banking as a depository of funds and credit distribution has a strategic role in realizing national development, especially economic development because through banking the public has access to improve their standard of living through credit provided by banks to the public. Credit activities provided by banks are expected to be able to explore the economic potential of the community through the capital provided by banks to the public. ${ }^{3}$ One of the banks that is present in the community with credit facilities is the Rural Bank (BPR). The existence of Rural Banks is very helpful in the economy, especially for small communities in terms of providing employment opportunities with access to capital. The existence of Rural Banks is closely related to the difficulties of the community, especially in small businesses so that the establishment of Rural Banks is one form of government policy to help small communities. ${ }^{4}$ Rural Bank itself is a special type of bank to serve small communities, namely providing banking services ${ }^{5}$, one of which is to provide credit services with softer requirements, as well as procedures and processes that are not complicated. ${ }^{6}$

As one of the banks that carries out banking functions in carrying out their activities, BPR recognizes the principle of prudence in credit activities as well as conventional banks in general. This is because in the distribution of funds to the public there is a big risk. Based on data released by the Research Center of Reform on Economics (CORE), it is stated that: non-performing loan (NPL) ratio BPR in 2020 reached $8.34 \%{ }^{7}$

The precautionary principle as regulated in Article 2 of the Banking Law is embodied in a bank credit agreement between the bank and the applicant (prospective debtor). The credit agreement is made based on the loan agreement as stipulated in Article 1754 of the Civil Code. The importance of the precautionary principle in credit agreements is to analyze the financial capabilities of prospective debtors, known as $5 \mathrm{C}$, the aspects of the $5 \mathrm{C}$ analysis

\footnotetext{
${ }^{2}$ Aqidatul Izza, (2017), Peran Historis Perbankan Dalam Perekonomian Indonesia. Dinar Jurnal Prodi Ekonomi Syari'ah, Vol. 1 No. 1, September 2017, p.21

${ }^{3}$ Muhamad Djumhana, (2000), Hukum Perbankan Di Indonesia, Bandung: PT. Citra Aditya Bakti, p. 2

${ }^{4}$ Pandu Suharto, (2001), Peran, Masalah, dan Prospek Bank Perkreditan Rakyat, Jakarta: LPPI, p. 8

${ }^{5}$ Ong Argo Victoria, Ade Riusma Ariyana, Devina Arifani. (2020). Code of Ethics and Position of Notary in Indonesia. Sultan Agung Notary Law Review 2 (4), 397-407, http://lppmunissula.com/jurnal.unissula.ac.id/index.php/SANLaR/article/view/13536 and see A Chuasanga, Ong Argo Victoria. (2019). Legal Principles Under Criminal Law in Indonesia and Thailand, Jurnal Daulat Hukum, Vol 2, No 1 (2019) http://jurnal.unissula.ac.id/index.php/RH/article/view/4218

${ }^{6} /$ bid, p.11

7 Ni Putu Eka, (2020), “Kredit Macet BPR mencapai angka 8,34 Persen” in www.bisnis.id, accessed on 31 September 2021
} 
are: Character (nature), Capacity (capability), Capital, Collateral, Condition of Economy. ${ }^{8}$

The credit agreement is a manifestation of the bank in applying the precautionary principle followed by an additional agreement, namely an agreement to provide guarantees by debtors in the form of mortgage guarantees as outlined in the Deed of Granting Mortgage Rights (APHT). Mortgage as collateral for bank credit is considered a guarantee that never harms because land is an object that will not decrease in price. As for the provisions on land that can be used as collateral objects, namely land owned by the debtor personally and land owned by a third party as a guarantor of debt from the debtor. ${ }^{9}$

Furthermore, related to the mortgage giver and holder in Articles 8 and 9 UUHT it is explained that the mortgage provider is a person or legal entity that has the authority to carry out legal actions against the object of the mortgage. Likewise, the holder of the mortgage is an individual or legal entity domiciled as a party to the debt. Seeing the provisions of Articles 8 and 9 of the UUHT, there should be no requirement that the debtor must be the provider of mortgage rights. This means that third parties can be used as mortgage providers even though they are not written rigidly in the UUHT and are only mentioned in the explanation of the UUHT, namely that mortgages fulfill the principles of speciality and publicity so that they can bind third parties and provide legal certainty to interested parties. ${ }^{10}$

The practice of guaranteeing mortgages belonging to third parties will not be a problem if the implementation of credit performance is in accordance with the agreement, but problems will occur if the debtor does not meet the performance and will cause losses, especially the land that is pledged does not belong to the debtor but belongs to a third party, especially since there are no rules that regulates expressly and clearly regarding the legal protection of collateral rights belonging to third parties or not belonging to the debtor. Included in Rural Banks where in practice there are still many mortgages that use certificates belonging to third parties, one example is in the City of Surakarta, where as many as more than 25 debtors use certificates belonging to third parties for reasons of convenience. ${ }^{11}$

\footnotetext{
8 Ashadil Diab, "Perjanjian Kredit Pada Bank Perkreditan Rakyat (Telaah Terhadap Penerapan Perkreditan Bpr Latunru Latinro)", in Jurnal Al-'AdI Vol. 10, No. 1, Januari 2017, p. 6

${ }^{9}$ Muh Akbar Ariz Purnomo, (2014), "Perlindungan Hukum Bagi Pemberi Hak Tanggungan yang Bukan Debitur Dalam Perjanjian Kredit" in Unnes Law Journal, Vol. 3, No. 1, p. 63

${ }^{10}$ See Elucidation of Article 11 and Article 13 of the Mortgage Law

${ }^{11}$ Puguh Indro Paksiko, (2019), Perlindungan Hukum Kreditur Pemegang Hak Tanggungan Dengan Objek Milik Pihak Ketiga Di BPR Purwa Artha Purwodadi, UMS Law Review, Vol. 1, No. 3, p. 2
} 
Looking at the provisions of Article 1131 of the Civil Code, it is stated that all objects of the debtor, both movable and immovable, both existing and new ones that will exist in the future, become dependents for all engagements made. This means that all of a person's assets become collateral for all debtor's debts where when the debt is due and he is negligent in fulfilling his obligations to creditors, the person's assets can be confiscated and auctioned, the proceeds of which are then used to fulfill obligations or pay debts to creditors. Seeing this provision means that the property belonging to a third party as collateral for the mortgage must be executed according to the agreed credit agreement.

Seeing the problems that occur regarding the execution of mortgage rights belonging to third parties that still leave problems, it is necessary to study the execution of mortgage rights belonging to third parties in Rural Bank credit agreements to find out how the legal basis, execution procedures, dispute resolution and legal protection.

\section{Research Methods}

The approach method used by the researcher is empirical juridical regarding the implementation of applicable regulations with direct events in the field or the community. Data collection is done by interviewing the parties concerned, both debtors, creditors and third parties. Data analysis method used qualitative analysis, where researchers process data obtained in the field with applicable regulations.

\section{Results and Discussion}

\subsection{Legal Overview of Third Party Land Mortgages}

One of the important elements in providing credit is a guarantee. The importance of collateral in credit activities at the bank is related to the ability of the debtor to fulfill his achievements against the bank through objects that are used as collateral that have economic value for the debt he receives. ${ }^{12}$ One form of guarantee known in the bank credit agreement is a mortgage right in the form of land that is charged to property rights, business rights and building rights as regulated in Article 4 to Article 7 of Act No. 4 of 1996 concerning Mortgage on Land and Objects Relating to Land. The bank credit agreement uses collateral for land rights in obtaining credit facilities because of the high economic value and increasing over time. ${ }^{13}$ Mortgage as collateral for credit in banking because it is a strong guarantee institution for immovable property in the form of land that is

\footnotetext{
${ }^{12}$ Rachmadi Usman, (2008), Aspek-Aspek Hukum Perbankan Di Indonesia, Jakarta: PT. Gramedia Pustaka Utama, p. 66

13 Ibid, p. 67
} 
used as collateral, because it provides a higher position (preference) for creditors holding Mortgage Rights compared to other creditors (droit de preference). ${ }^{14}$ In order to be able to obtain a bank credit facility, which in this case is a rural credit bank, the land to be used as collateral may belong to another person who does not belong to the debtor or is often known as the property of a third party. The third party involved in the credit agreement means that the third party can bear the repayment of credit by the Debtor as described in Article 1820 of the Civil Code, namely:

"Insurance is an agreement by which a third party, for the benefit of the debtor, binds himself to fulfill the obligation of the debtor when this person himself does not fulfill it."

Juridically, if a third party finds out that their land is used as the object of a bank loan which is then listed in the Deed of Granting Mortgage Rights (APHT), it will bring consequences and responsibilities to the related parties, including the third party. This means that the third party agrees on all risks that may arise in the implementation of the mortgage agreement, namely the possibility of default in the future.

\subsection{Execution of Mortgage Guarantees Owned by Third Parties on Credit at Rural Banks}

In the event that the debtor defaults, the mortgage right in the form of land belonging to a third party refers to Article 6 of Act No. 4 of 1996 concerning Mortgage on Land and Objects related to Land, namely:

"If the debtor is in breach of contract, the holder of the first Mortgage has the right to sell the object of the Mortgage on his own power through a public auction and take repayment of his receivables from the proceeds of the sale."

In relation to the execution of collateral rights belonging to third parties as written in Article 6 of the UUHT, it provides the right for Mortgage holders to parate execution. This means that the holder of the Mortgage does not need not only to obtain approval from the Mortgage provider, but also does not need to ask for a determination from the local court if he is going to execute the Mortgage which is the guarantee for the debtor's debt in the event that the debtor is in default. In addition, referring to the mortgage certificate issued by the land office, it contains "BASED ON JUSTICE BASED ON THE ONE ALMIGHTY GOD" which means that the existence of these irahs shows that the mortgage

\footnotetext{
${ }^{14}$ Andika Tanaya Setiadi, (2020), Analisis Upaya Hukum Pihak Ketiga Terhadap Eksekusi Benda Jaminan, NOTARIUS, Vol. 13, No. 1, p 221
} 
certificate has permanent legal force and is valid as a substitute for the grosse acte hypoteek as long as it concerns rights. over the ground. ${ }^{15}$

Looking at the provisions regarding bank credit agreements with additional agreements that bind the debtor, in this case the debtor uses land as collateral for mortgages belonging to a third party, in relation to the execution of the guarantee, if there is a default by the debtor, the third party has the responsibility to bear everything, especially accepting if the execution is carried out. Mortgage rights due to debtors trusted by third parties are in default. With the issuance of APHT, it brings consequences and responsibilities to the parties involved in binding collateral with the risk of losing assets.

The imposition of mortgage rights in the case of third parties knowing that their assets are objects of mortgage guarantees as happened in BPR X, in this case the debtor on behalf of Asnawi defaulted on the credit in the credit agreement at the BPR where Asnawi as the debtor used land with a certificate of ownership. Suroyo and Suroyo knew that in the end, an execution was carried out on the land as the object of the mortgage. BPR X as the holder of Mortgage Rights then executed the land due to a default. According to the author, BPR X has the right to execute the mortgage right through a public auction which legally refers to Article 6 of the UUHT.

Public auction of Mortgage is regulated in Article 30 PMK No. 135/PMK/2006 is carried out by the Office of the State Assets and Auction Service (KPKNL) where the task of the KPKNL is to carry out services in the fields of state assets, valuation, state receivables, and auctions. The execution of the Mortgage Rights in this case was carried out with the intermediary of the KPKNL, because it is based on Attachment II to the Regulation of the Minister of Finance Number 135/PMK.01/2006 concerning the Organization and Work Procedure of the Vertical Agency of the Directorate General of State Assets, the working area of the KPKNL. Based on this, according to the author, it is true that the implementation of the Mortgage Execution auction is carried out with the intermediary of the KPKNL in the BPR area.

The implementation of the execution of Mortgage that is controlled by a third party sometimes causes problems, namely the resistance of a third party. If a third party resists by filing a lawsuit to the District Court. However, even though a lawsuit has been filed by a third party based on Article 207 point 3 HIR jo. Book II of the Technical Guidelines for the Administration of General Courts of third party resistance does not delay the execution. Based on this, even though there is resistance to the execution of the auction, the execution of the auction can still be carried out. As for the claim that is being sued, namely dealing with the mortgage, a third party who can prove that the goods to be confiscated belongs

\footnotetext{
${ }^{15}$ David Adrian. (2014). Legal Protection Against Creditors for Mortgage Objects From Efforts to Seize Guarantees by Third Parties. Journal of Lex Privatum, Vol. 1, No. 2, p. 14.
} 
to him, then his resistance is granted. ${ }^{16}$ This means that if in the lawsuit process there is no strong evidence of ownership, the execution will still be carried out, as well as if the third party as the owner of the mortgage has known at the outset that his land is used as mortgage in the credit agreement, then there can be no resistance.

\section{Conclusion}

The involvement of third parties in bank credit agreements at Rural Banks (BPR) in guaranteeing land rights can be explained by looking at several provisions in Act No. 4 of 1996, namely in Article 1 paragraph (2), (3), (4), (6) concerning the parties involved in the mortgage. The provisions of the third party as the owner of the mortgage on the land are legally binding on the acts of engagement made by the debtor and creditor which have the consequence of losing their assets if the debtor defaults. For defaults committed by third party debtors, they have the responsibility to bear everything, especially accepting if the mortgage is executed because the debtor trusted by the third party is in default. With the issuance of APHT, it brings consequences and responsibilities to the parties involved in the binding of collateral with the risk of losing assets. Legal remedies for third parties as owners of land rights that are used as objects of mortgage rights are that they can file a lawsuit or derden verzet to the District Court, although this method cannot in principle suspend execution (Article 207 paragraph (3) HIR and 227 $\mathrm{RBg}$ ) especially if from the start the third party agrees that the land is used as collateral for mortgage rights.

\section{References}

Journals:

[1] A Chuasanga, Ong Argo Victoria. (2019). Legal Principles Under Criminal Law in Indonesia and Thailand, Jurnal Daulat Hukum, Vol 2, No 1 (2019) http://jurnal.unissula.ac.id/index.php/RH/article/view/4218

[2] Andika Tanaya Setiadi, (2020), Analisis Upaya Hukum Pihak Ketiga Terhadap Eksekusi Benda Jaminan, NOTARIUS, Vol. 13, No. 1

[3] Aqidatul Izza, (2017), Peran Historis Perbankan Dalam Perekonomian Indonesia. Dinar Jurnal Prodi Ekonomi Syari'ah, Vol. 1 No. 1, September 2017

[4] Ashadil Diab, "Perjanjian Kredit Pada Bank Perkreditan Rakyat (Telaah Terhadap Penerapan Perkreditan Bpr Latunru Latinro)", in Jurnal Al-'Adl Vol. 10, No. 1, Januari 2017

\footnotetext{
${ }^{16}$ Heru Sugiyono, (2017), Perlindungan Hukum Terhadap Pihak Ketiga Sebagai Pemilik Jaminan Ketika Tidak Dilaksanakannya Prinsip Kehati-Hatian Oleh Bank Dalam Perjanjian Kredit Dengan Memakai Jamina, Jurnal Yuridis Vol. 4 No. 1, p. 98-109
} 
[5] David Adrian, (2014), Perlindungan Hukum Terhadap Kreditur Atas Objek Hak Tanggungan Dari Upaya Sita Jaminan Oleh Pihak Ketiga, Jurnal Lex Privatum, Vol. 1, No. 2

[6] Heru Sugiyono, (2017), Perlindungan Hukum Terhadap Pihak Ketiga Sebagai Pemilik Jaminan Ketika Tidak Dilaksanakannya Prinsip KehatiHatian Oleh Bank Dalam Perjanjian Kredit Dengan Memakai Jamina, Jurnal Yuridis Vol. 4 No. 1

[7] Muh Akbar Ariz Purnomo, (2014), "Perlindungan Hukum Bagi Pemberi Hak Tanggungan yang Bukan Debitur Dalam Perjanjian Kredit" in Unnes Law Journal, Vol. 3, No. 1

[8] Ong Argo Victoria, Ade Riusma Ariyana, Devina Arifani. (2020). Code of Ethics and Position of Notary in Indonesia. Sultan Agung Notary Law $\begin{array}{llll}\text { Review } & 2 & \text { (4), 397-407, http://lppm- }\end{array}$ unissula.com/jurnal.unissula.ac.id/index.php/SANLaR/article/view/13536

[9] Puguh Indro Paksiko, (2019), Perlindungan Hukum Kreditur Pemegang Hak Tanggungan Dengan Objek Milik Pihak Ketiga Di BPR Purwa Artha Purwodadi, UMS Law Review, Vol. 1, No. 3

Books:

[1] Muhamad Djumhana, (2000), Hukum Perbankan Di Indonesia, Bandung: PT. Citra Aditya Bakti

[2] Pandu Suharto, (2001), Peran, Masalah, dan Prospek Bank Perkreditan Rakyat, Jakarta: LPPI

[3] Rachmadi Usman, (2008), Aspek-Aspek Hukum Perbankan Di Indonesia, Jakarta: PT. Gramedia Pustaka Utama

[4] Thomas Suyatno, (2001), Kelembagaan Perbankan, Jakarta: Gramedia Pustaka Utama

Internet:

Ni Putu Eka, (2020), "Kredit Macet BPR mencapai angka 8,34 Persen" in www.bisnis.id, accessed on 31 September 2021 